\title{
Ocean warming and long-term change in pelagic bird abundance within the California current system
}

\author{
Richard R. Veit ${ }^{1, *}$, Peter Pyle ${ }^{2}$, John A. McGowan ${ }^{3}$ \\ ${ }^{1}$ Department of Zoology, Box 351800, University of Washington, Seattle, Washington 98195-1800, USA \\ ${ }^{2}$ Point Reyes Bird Observatory, 4990 Shoreline Highway, Stinson Beach, California 94970, USA \\ ${ }^{3}$ Scripps Institution of Oceanography, La Jolla, California 92093, USA
}

\begin{abstract}
As a result of repeated sampling of pelagic bird abundance over $3 \times 10^{5} \mathrm{~km}^{2}$ of open ocean 4 times a year for $8 \mathrm{yr}$, we report that seabird abundance within the California Current system has declined by $40 \%$ over the period 1987 to 1994. This decline has accompanied a concurrent, long-term increase in sea surface temperature. The decline in overall bird abundance is largely, but not entirely, a consequence of the $90 \%$ decline of sooty shearwaters Puffinus griseus, the numerically dominant species of the California Current. Seabirds of the offshore waters we sampled showed a different pattern from seabirds of the shelf and slope waters. Leach's storm-petrels Oceanodroma leucorhoa, the commonest species offshore, significantly increased during 1987 to 1994 , while sooty shearwaters and other inshore species declined. Thus the clearest pattern that emerges from our data is one of gradual but persistent changes in abundance that transpire at time scales longer than 1 yr. Nevertheless, we did find evidence of change at shorter time scales (weeks and months) that may relate to the El Nino episode of 1992 to 1993: Pronounced positive anomalies of abundance of brown pelicans Pelecanus occidentalis and Heerman's gulls Larus heermani in fall 1991, and black Oceanodroma melania and least O. microsoma storm-petrels in late summer 1992, likely reflect northward dispersal following reproductive failure in the Gulf of California.
\end{abstract}

KEY WORDS: Climate change Pelagic birds California Current - El Niño Southern Oscillation - Sooty shearwater-Leach's storm-petrel

\section{INTRODUCTION}

Roemmich (1992) demonstrated a long-term increase in ocean temperatures off southern California, USA, during the period 1949 to 1990. This analysis was based on data collected by CalCOFI (California Cooperative Oceanic Fisheries investigations; see Chelton et al. 1982). Because biological productivity of the ocean is closely linked to ocean temperature as an index of the processes of advection and upwelling (Chelton et al. 1982), it seems likely that the decadal temperature change described by Roemmich (1992) would indicate other changes which would have some influence upon the biological populations of the Cali-

•E-mail:veitrr@zoology.washington.edu fornia Current. If such an influence is evident, then it should be evident among upper trophic level consumers such as pelagic birds.

Ainley et al. $(1994,1996)$ have demonstrated coupling between seabird reproductive variables at the Farallon Islands (off San Francisco, USA) and ocean temperature. Seabirds at the Farallons responded to variation in sea temperatures at an annual time scale, especially following El Niño Southern Oscillation (ENSO) events. Reproductive variables such as egglaying dates and number of chicks fledged change for the worse during warm water years, then return to more nearly average values the following year.

The combined analyses of Roemmich (1992) and Chelton et al. (1982), however, suggest that considerable variability of biological processes in the California Current exists at time scales greater than a year. We 
examine whether the longer-term variability of physical and biological processes within the California Current described by Chelton et al. (1982) and Roemmich (1992) are tracked by upper level consumers. Thus, we seek to detect changes in abundance of pelagic birds that take place over periods of longer than 1 yr

We began measuring the abundance of pelagic birds within the California Current as part of CalCOFI in May 1987. Since that time, we have collected data on birds on 29 CalCOFI cruises, 4 per year between 1987 and 1994. One of our main objectives has been to determine whether bird abundance is responsive to the longer-term variability of the sort described by Chelton et al. (1982), and specifically whether variation in bird abundance reflects changes in sea temperature and zooplankton abundance (Roemmich \& McGowan 1995). It is well known that seabird abundance fluctuates seasonally in accord with the breeding and migratory schedules of the component species (Ainley 1976, Briggs et al. 1987). However, it has not been possible to quantify long-term variability of pelagic populations of birds in the past due to the lack of repeated, quantified sampling of birds at sea. The CalCOFI cruises have provided a unique opportunity to fill this gap.

The impact of El Niño events upon seabird populations has been known for years (Murphy 1936), and variations in pelagic bird populations off California have been attributed to short-term changes in ocean temperatures (Ainley 1976). What is novel about our approach is the opportunity to sample the same section of ocean repeatedly over an 8 yr period and to relate data on bird abundance to data on physical oceanography collected simultaneously. In this paper, we focus specifically on the relation between ocean temperature and bird abundance. We address the question: 'Does the recently documented increase in sea temperature off southern California affect the abundance of birds in that area, and if so, which species are most affected. and over what temporal scale is their numerical response most evident?

\section{METHODS}

The CalCOFI sampling grid consists of 65 oceanographic stations distributed along 6 transect lines that are oriented northeast-southwest, and span the width of the California Current System (Fig 1). The northernmost line is based at Avila Beach, San Luis Obispo County, California, USA, and is $470 \mathrm{~km}$ long, while the southernmost line is based at La Jolla, San Diego County, CA, USA, and is $700 \mathrm{~km}$ long The offshore stations are situated 40 nautical miles $(76 \mathrm{~km})$ apart,

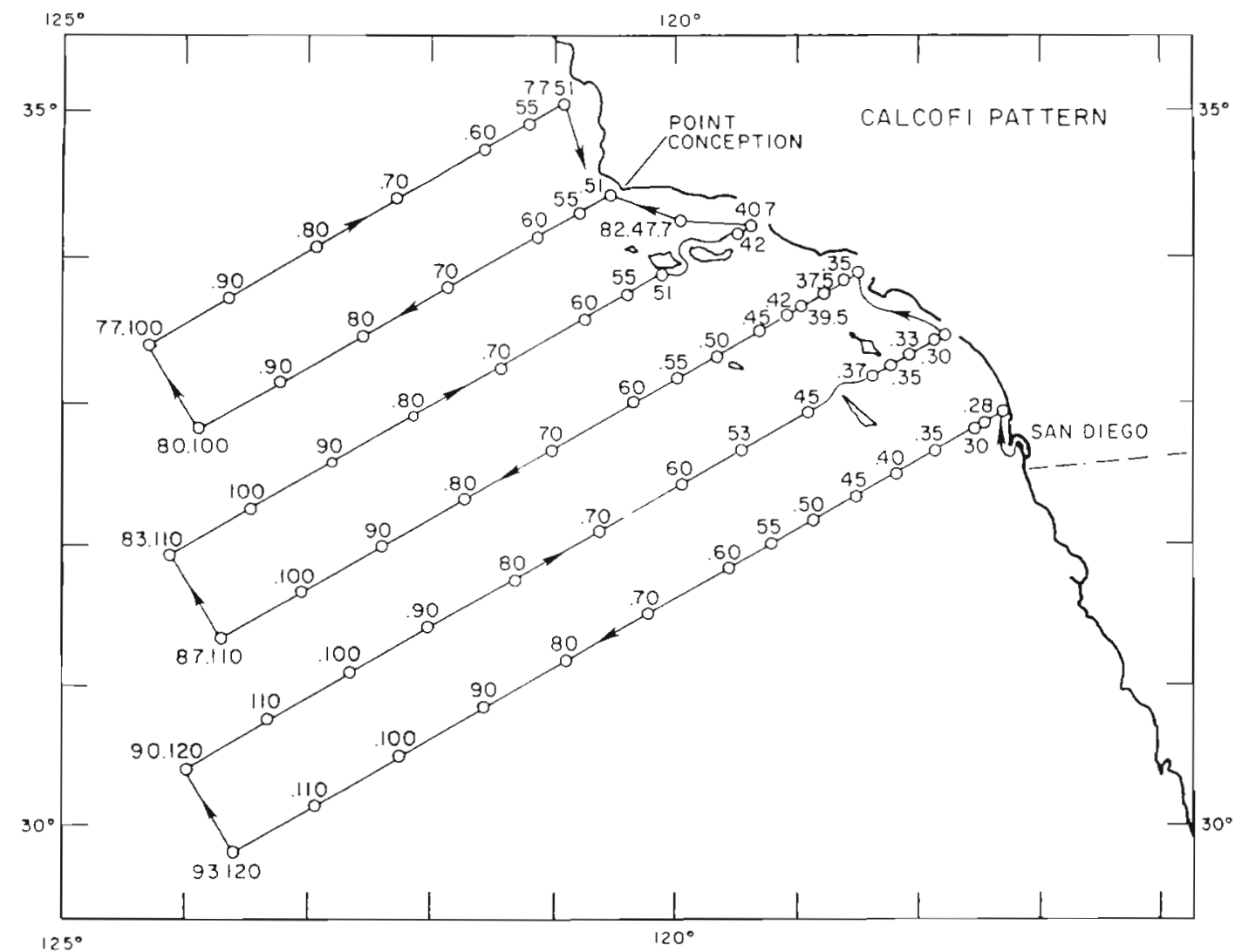

Fig. 1 Cruise track sampled by CalCOFI off the coast of California, USA 
and the spacing of the inshore stations is variable, from 5 to $38 \mathrm{~km}$. We collected data on birds only during daylight hours while the ship was underway between stations, and so surveyed an average of $1600 \mathrm{~km}$ of transect per cruise. We make frequent use of the unit 'nautical mile' (NM) because of convenience, but present metric equivalents throughout the text for comparability to other studies.

We sampled bird abundance using strip transects. We counted all birds within a $300 \mathrm{~m}$ wide strip extending to one side of the ship's trackline. We watched continuously while the ship was underway rather than taking intermittent samples. Birds judged to be ship followers were counted when first observed and ignored thereafter. (Few birds follow the ship on CalCOFI cruises; those that do are mainly black-footed albatrosses Diomedea nigripes.) Our basic unit of measurement of bird abundance is number of birds recorded per NM of transect (= birds per $0.555 \mathrm{~km}^{2}$, the area of a rectangle with sides $1 \mathrm{NM}$, or $1.851 \mathrm{~km}$, and $300 \mathrm{~m}$ ). Our data base consists of birds counted on 29 consecutive cruises, 4 per year, from May 1987 to April 1994. On these 29 cruises, we surveyed $43000 \mathrm{~km}$ of ocean and tallied 116000 birds.

To search for long-term trends in the time series of bird abundance, we wanted to minimize the variability due to seasonal fluctuations. Most of the birds that occur within the California Current System reside there for only 1 or 2 seasons of the year (Ainley 1976 . Briggs et al. 1987). We wanted to reduce variability resulting from seasonality within the time series so as to emphasize longer-term changes. To do this, we calculated 'seasonal anomalies', as follows: From our time series of 29 data points, we calculated seasonal means, by, for example, summing the birds counted on all 8 spring cruises then dividing by 8 . Then we subtracted the seasonal mean values from each of the original 29 data points. For example, we subtracted the spring mean value from the May 1987 value to produce the May 1987 value for seasonal anomaly. This procedure was performed for each of 4 seasons. The seasons were defined as follows: winter: January-February; spring. March-May; summer July-September; fall: OctoberNovember.

To provide an index of sea temperatures within the oceanic region sampled by CalCOFI, we calculated the mean of the temperatures measured at $10 \mathrm{~m}$ beneath the surface on all 15 stations along CalCOFI Line 90, which reaches the coast at Dana Point, Orange County, CA, USA. To calculate temperature anomalies, we used the same computational procedure described for the bird data. That is, we calculated seasonal means, based on 7 or 8 cruises for each season, then subtracted these seasonal means from the values measured on each cruise. Thus a temperature anomaly of zero on a fall cruise would mean that the mean value of $10 \mathrm{~m}$ temperatures from Line 90 was equal to the fall mean.

To detect trends in the data, we used regression analysis, and estimated statistical significance of the regression slopes using randomization tests (Manly 1991, Schneider \& Heinemann 1996). We also searched for links between changing sea temperatures and bird abundance with cross-correlation analysis, using the following rationale:

It is unlikely that bird populations respond instantaneously to changes in sea temperature. What we hypothesize to have happened is that reduced advection and upwelling would have led to both increased sea temperatures and reduced supplies of nutrients, which would have in turn resulted in smaller phytoplankton populations. The effects of reduced phytoplankton would eventually be translated to birds via reduced zooplankton populations. Therefore, we expected that changes in bird abundance would lag behind changes in temperature by an undetermined amount of time. To identify time lags in the response (if any) by birds to changing temperature, we used crosscorrelation analysis. Using this procedure, a series of Pearson correlation coefficients is calculated, each at a different temporal lag for example, relating bird abundance to temperature at a lag of -3 , we would match bird abundance in January 1993 with temperature measured 3 cruises (about 9 mo) earlier. The negative sign indicates the direction of the lag, in this case temperature leading birds rather than birds leading temperature. Our primary intent was to describe over what temporal scales seabirds might respond to changing temperatures, rather than to test any one particular hypothesis. Nevertheless, we wanted to evaluate the possibility that our results arose due to chance. Therefore, we used randomization tests to evaluate the statistical significance of correlation coefficients within our cross-correlation analyses. We randomly rearranged bird values relative to temperature values 100 times, and counted the number of coefficients obtained that were larger in absolute value than those obtained with the original data. The randomization tests were performed using an algorithm suggested by Press et al. (1989). All other statistical calculations were performed using SYSTAT (Wilkinson 1988).

\section{RESULTS}

\section{Temperature anomalies and overall bird abundance}

The pattern of temperature anomalies for the period 1987 to 1994 is one of sharp increase in the early years followed by comparatively small fluctuations (Fig. 2A). In the context of the entire $40 \mathrm{yr}$ time series analyzed 

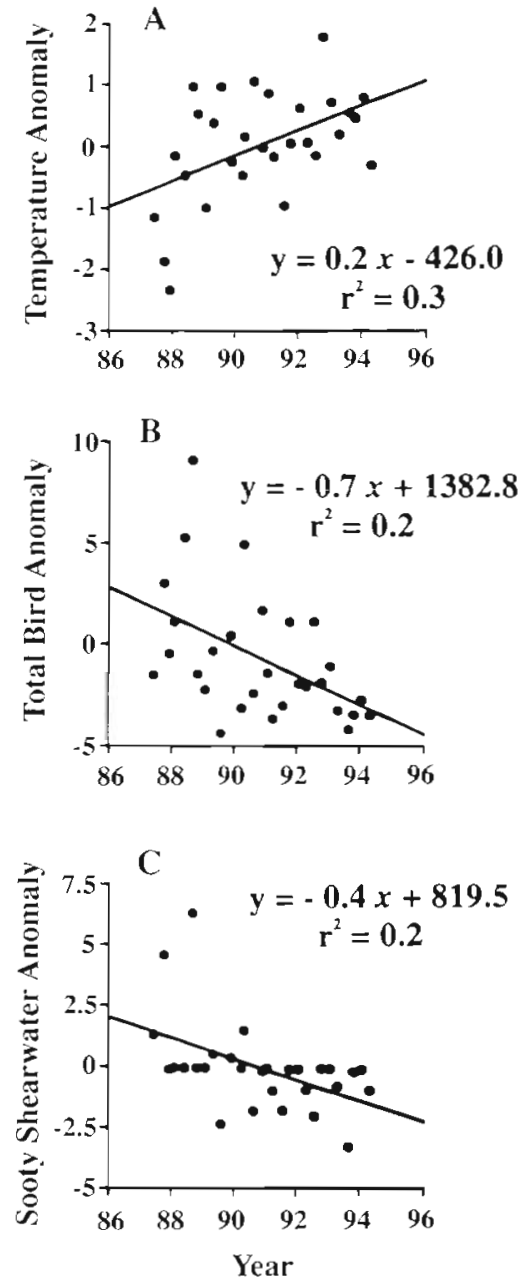

Fig. 2. (A) Time senes of subsurface sea temperature from 29 CalCOFI cruises. Data are seasonal anomalies, so that values for each season represent deviations from that season's means $(\mathrm{N}=7$ or 8$)$, not from the overall mean. Temperature measurements are means for bottles at $10 \mathrm{~m}$ depth from all $13 \mathrm{sta}-$ tions along CalCOFI Line 90.0. (B) Anomalies of seabird abundance (all species) for the same 29 cruises. The overall mean (non-seasonally corrected) was 4.2 birds per nautical mile. (C) Anomalies of sooty shearwater abundance for same 29 cruises. Statıstical significance of regression slopes estimated as $p<0.01$ using randomization

by Roemmich (1992) and Roemmich \& McGowan (1995), 1987 and 1988 were anomalously warm. This perspective emphasizes the long-term ecological nature of temperature change within the California Current. One especially large temperature anomaly in October 1992 (Fig. 2) likely represents the 1992-1993 El Niño for southern California.

The (seasonally corrected) total number of seabirds counted on CalCOFI cruises declined significantly ( $\mathrm{p}<$ 0.01 estimated by randomization) over the period 1987 to 1994 (Fig. 2B). The (non-seasonally corrected) mean bird density over all 29 cruises that we recorded was
Table 1. Change in abundance illustrated by comparisons of means during the years 1987-1988 and 1993-1994. Eight cruises were included for each pair of years. Mean values are means of anomalous abundance

\begin{tabular}{|lccl|}
\hline Group or species & $\begin{array}{c}\text { Percent } \\
\text { change }\end{array}$ & $\begin{array}{c}\text { Mann-Whitney } \\
U\end{array}$ & Signif. \\
\hline All seabirds & -42 & 40 & $p<0.007$ \\
Sooty shearwater & -91 & 34 & $p=0.06$ \\
Leach's storm-petrel & +162 & 4 & $p=0.015$ \\
\hline
\end{tabular}

4.2 birds per NM ( 7.6 birds per $\left.\mathrm{km}^{2}\right)$. To give an idea of the magnitude of the changes in abundance that have occurred, we calculated mean abundances for the first 8 cruises on which we collected data (May 1987 to January 1989) and compared these to those from the last 8 cruises (July 1992 to April 1994) (Table 1). Since sooty shearwaters made up $>50 \%$ of all birds seen on the cruises, their decline dominates the community pattern.

Anomalies of bird abundance were significantly correlated with temperatures recorded on cruises $9 \mathrm{mo}$ previously (Fig. 3). The shape of this cross-correlation function, with a strong peak at a lag of $-3(r=-0.57, p<$ 0.01 by randomization) and no indication of positive correlation at any lag, clearly indicates that bird numbers declined in response to marine conditions typical of the preceding months. The peak in the cross-correlation plot at a lag of -3 ( 9 mo, or 3 cruises, previously) suggests the possibility that birds decided whether to return to the California Current System based on their estimation of availability of food there the previous year.

\section{Bird and Temperature Anomalies}

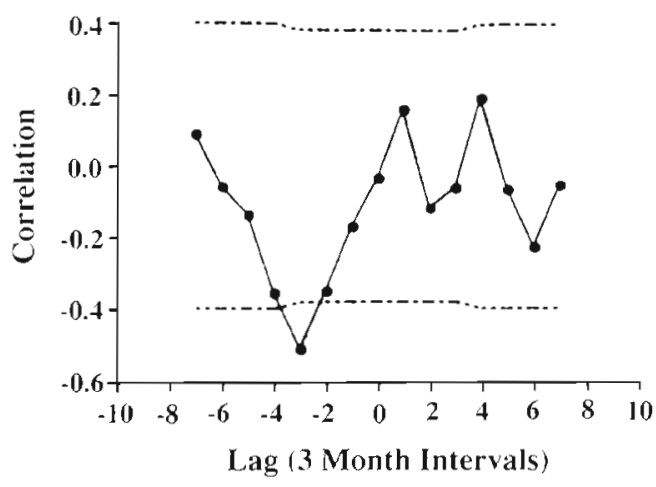

Fig. 3. Time lag of response by birds to changing temperatures. Data points represent values of correlation coefficients, calculated for differing temporal lags, between anomalies of temperature and bird abundance. Statistical significance is indicated by the horizontal dashed lines. Thus, correlation at a time lag of -3 was statistically significant, meaning that bird abundance was most closely related to temperature values recorded approximately 9 mo (3 cruises) previously 
We used the pattern illustrated in Fig. 3 to select species out of those we sampled whose abundance seemed particularly closely related to changing sea temperature. Then we isolated the 15 most numerous species recorded during the 8 yr period. To do this, we calculated cross-correlation functions between anomalies of bird abundance and temperature for the 29 cruises. Among this grouping we could expect to find about 1 correlation significant at the 0.01 level due to chance. We found 6 such species (including sooty shearwater and Leach's storm-petrel), 3 of which were negative. These negative correlations indicated declining abundance in response to increasing temperature. There were 2 additional species (aside from the 6 whose change in abundance was linked to changing temperature), black and least storm-petrels, that were positively correlated with sea surface temperature, but at a positive lag. That is, warm sea temperatures followed periods of increased abundance of these species.

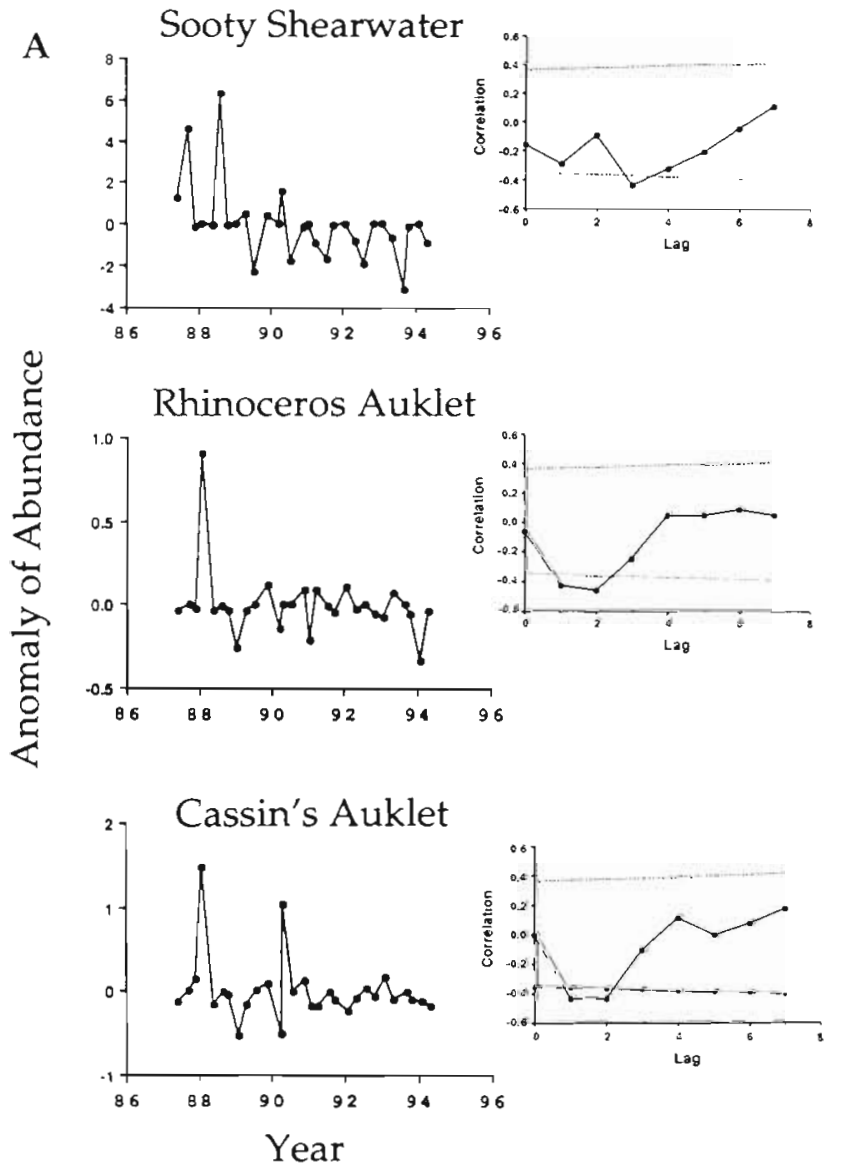

\section{Negative response to temperature}

The overall trend in bird abundance in 1987 to 1994 was negative, and this trend was mirrored in the decline of the most numerous species that we recorded, the sooty shearwater (Fig, 4A). Sooty shearwaters declined from 2.6 to 0.2 birds per NM ( 4.7 to 0.4 birds per $\mathrm{km}^{2}$, or by more than $90 \%$. The decline was not uniform over the $8 \mathrm{yr}$ period, but instead resembled the inverse of the pattern of increasing temperature: sooty shearwater abundance was very high during 1987 and 1988, then declined to low levels for the remainder of the period.

The 2 species, aside from sooty shearwater, that were negatively related to temperature anomaly were rhinoceros Cerorhinca monocerata and Cassin's Ptychoramphus aleuticus auklets (Fig. 4A). The statistical significance of each correlation coefficient plotted in Fig. 4 was checked by randomization. Since we calculated multiple coefficients for each set of data, we fur-
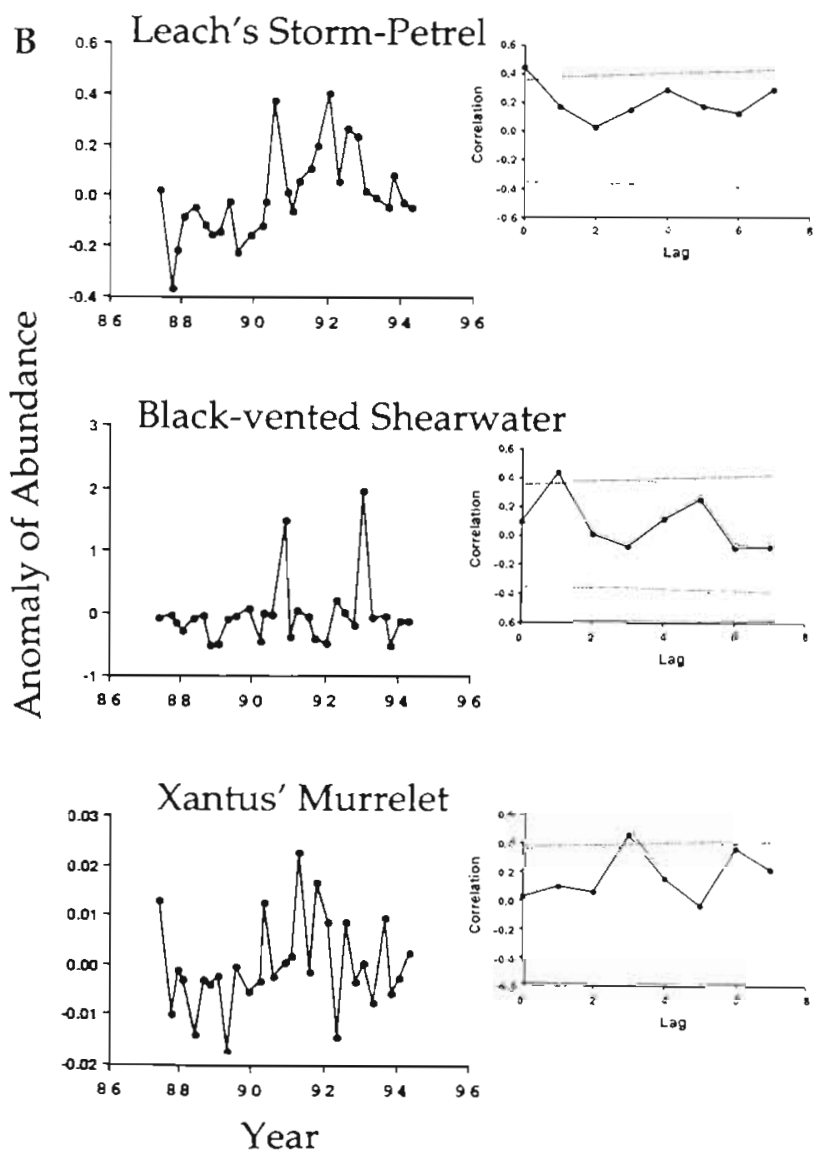

Fig. 4. (A) Time series of abundance of 3 species negatively correlated with temperature anomaly; these species have decreased with increasing temperatures. The cross-correlations between bird and temperature anomaly are graphed on the right. (B) Three species positively correlated with temperature anomaly; these species have increased with increasing temperatures. Crosscorrelations graphed on the right. Lags were computed in only 1 direction, temperature change preceding bird change, so negative signs have been left out 
ther evaluated the significance of the bird-temperature relationships by asking the following question using randomization tests: 'Out of 100 randon rearrangements of the data, how many yielded coefficients, within a lag of 3 or less ( $1 \mathrm{yr}$ ), that were larger than those obtained using the real data?' This procedure is analogous to using the Bonferroni correction for multiple tests. The estimated significance levels were $p=$ 0.12 for sooty shearwater and $p<0.01$ for the 2 auklets. These 3 species, all characteristic of inshore waters and high latitudes, typically seek cold waters for foraging (Briggs et al. 1987) Like sooty shearwaters, both rhinoceros and Cassin's auklets have declined unevenly since 1987. With the exception of a large count of Cassin's auklets in spring 1990, both alcids were abundant in 1987 and then declined to low levels where they remained through 1994. Thus, despite the correlation with temperature at lags of 3 to 6 mo, there was no significant trend in abundance for either of the 2 alcids

\section{Positive response to temperature}

Three species increased in response to increasing temperatures. These were Leach's storm-petrel, blackvented shearwater and Xantus' murrelet Synthliboramphus hypoleuca (Fig. 4B). The significance levels, estimated by randomization and allowing for muitiple tests, were $\mathrm{p}=0.02$ for Leach's storm-petrel, $\mathrm{p}=0.05$ for black-vented shearwater and $p<0.01$ for Xantus' murrelet. Leach's storm-petrel is the dominant species of offshore waters within the region surveyed by $\mathrm{Ca}$ COFI, black-vented shearwater is found close to shore, and Xantus' murrelet tends to be most numerous along the offshore slopes of the channel islands. Leach's storm-petrels increased from 0.13 to 0.33 birds per NM ( 0.23 to 0.59 birds per $\mathrm{km}^{2}$ ), or by $160 \%$. Leach's stormpetrel was unique in its pattern of tracking of temperature; correlation of storm-petrel abundance anomaly with temperature anomaly was highest at a lag of zero (Fig. 4B). Leach's storm-petrels increased in abundance until the winter of 1992 and then declined. Xantus' Murrelet also increased to peak abundance in late 1991/early 1992, but correlation between murrelet and temperature anomaly was highest at a lag of $9 \mathrm{mo}$. Black-vented shearwaters showed 2 'spikes' of abundance, in fall 1990 and winter 1993, and were most highly correlated with temperature anomaly at a lag of 3 mo

\section{Short term response to El Niño}

Two species, brown pelican and Heerman's gull, invaded the CalCOFI region in the fall of 1991 (Fig. 5). This pattern suggest a response to the 1992-1993 El Nirio (Hayward 1993), yet the abundance of these species in the CalCOFI area was not correlated with temperature anomaly. We speculate that large numbers of these species dispersed northwards following reproductive failure within the Gulf of California during summer 1991. That is, effects of the El Niño may have been felt earlier in the Gulf of California than they were off southern California. Black and least stormpetrels appeared in peak abundance during the late summer 1992, or just before the October peak of the $\mathrm{El}$ Niño of southern California.

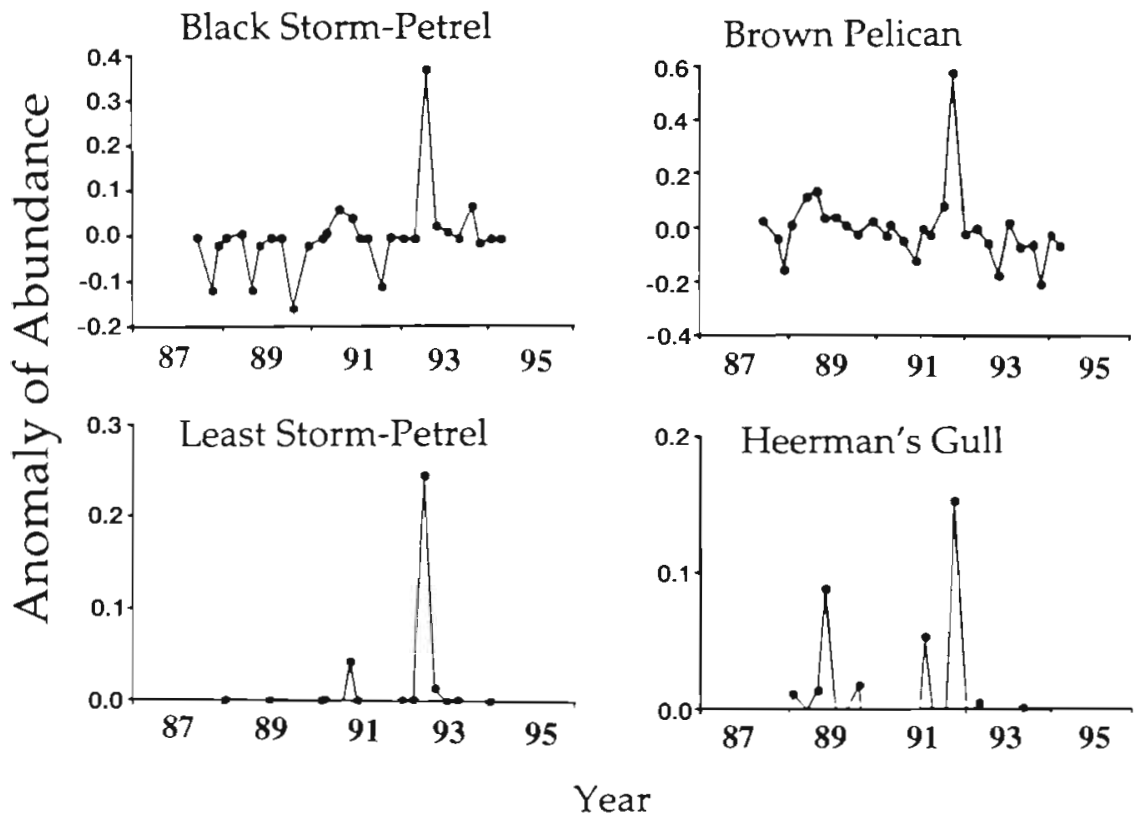

Fig. 5. Short-term $(<1$ yr) response by brown pelicans, Heerman's gulls and black and least storm-petrels to El Niño-like conditions in 19921993. The pulses for the pelican and gull species were both recorded during October 1991, and those for the storm-petrels ivere recorded in August 1992 


\section{DISCUSSION}

We cannot ascribe the changes in bird abundance that we have quantified directly to population dynamics, for 2 reasons. First, the foraging ranges of the species concerned are very large, some (e.g. sooty shearwater) encompassing the entire Pacific Ocean. Therefore, changes in abundance recorded locally, even over as large an area as is covered by the CalCOFI pattern, could just as easily be due to distributional shifts as changes in overall population sizes. Second, the life spans and generation times are so long for seabirds (tens of years) that impacts of environmental episodes such as El Niño are unlikely to be felt as changes in overall abundance during the 8 yr that we collected data. Nevertheless, the changes in abundance that we have documented are substantial and persistent, and must reflect considerable biological change taking place within the California Current System.

We had the best chance of recording changes in overall population size for those species that are resident within the area surveyed by CalCOFI, and which occur in substantial numbers on our surveys. Species that best meet these criteria include Brandt's (Phalacrocorax penicillatus) and pelagic ( $P$. pelagicus) cormorants, western gull and Xantus' murrelet. Of these 4 species, none showed a significant decline in abundance and 1, Xantus' murrelet, significantly increased. Cassin's and rhinoceros auklets are resident within the California Current System, yet breed mainly to the north of the CalCOFI region and occur there primarily in winter Both species declined significantly within the area sampled by CalCOFI since 1987 Carter et al. (1992) showed that Cassin's auklet declined substantially as a breeder in California since the early 1970 s. In contrast, Ainley et al. (1994) showed that rhinoceros auklets have dramatically increased throughout their northeast Pacific range beginning in the mid 1970 s. Thus, for both these species of alcids, the decline we have recorded off southern California seems particular to their winter distributions rather than reflective of overall population size

Sooty shearwaters breed on small and remote islands off the coasts of New Zealand and southern South America (Warham \& Wilson 1982), and there is no information available on possible changes in the size of the major colony at the Snares Islands, New Zealand (J. Warham pers. comm.) or elsewhere within their large breeding range. For this reason, we cannot determine whether the dramatic decline of sooty shearwaters off southern California represents a distributional shift or a population decline. However, we have been able to examine whether the decline that we have recorded off southern California might be the result of a distributional shift to northern California or Washington, USA, and it seems not to have been. D. G. Ainley (pers. comm.) and his colleagues have been surveying birds at sea off San Francisco each spring since 1986, and have recorded a substantial decline that is closely correlated in time (peak abundance in 1988 , declining steeply thereafter) with our southern California data. T R. Wahl (pers. comm.) has been surveying seabirds off Westport, Washington, annually since 1972 and has noted a persistent decline since 1988, or the same pattern that we have witnessed of southern California

Whatever the cause, though, there can be no doubt that a $90 \%$ decrease in the number of sooty shearwaters feeding off southern California reflects a dramatic change in biological conditions, and could substantially affect at the very least those species upon which sooty shearwaters feed. Chu (1984) estimated that 2 to 4 million sooty shearwaters visited the California Current System each year, and that they consumed 200 to $300 \mathrm{~g}$ each of fish, squid and euphausiids per day while accumulating fat for the migratory flight back to the breeding grounds.

It is possible that the decline of sooty shearwaters that we have documented of southern California could be partly the result of gill-net mortality in the North Pacific. Johnson et al. (1991) estimated that 235000 sooty shearwaters were killed in the North Pacific squid fishery in 1990; an estimate extrapolated from an actual count of 20000 sooty shearwater carcasses made by observers on fishing boats

The important message we wish to emphasize is the $>1$ yr time scale over which the changes we have reported have taken place. In particular, our findings of long-term response of bird abundance to changes in ocean temperature contrast with the short-term response of reproductive parameters described by Ainley et al. (1996). This contrast suggests that survivorship after fledging may contribute to overall population size more strongly than does fledging success as measured at the colony. Despite the uncertainty about whether our data on abundance reflects movement behavior more than population dynamics, our analyses at the very least point to the importance of contrasting and integrating pelagic surveys with reproductive data collected at the breeding colony in evaluating the status of populations of seabirds. Furthermore, if bird abundance fluctuates in response to environmental change as indexed by sea surface temperature, as we have shown, and if sea temperature fluctuates with the decadal time scale shown by Roemmich (1992) and Chelton et al. (1982), then the time scale at which this variability transpires needs to be taken into account by modellers interested in predicting effects of global climate change upon animal populations. The CalCOFI 
time series show strong autocorrelation; warm and cold periods alternate but each lasts on average more than 1 yr. From a seabird's perspective, this means that a 'poor' year is likely to be followed by additional poor years and vice versa. Sooty shearwaters of California seem to have experienced 6 poor years in a row. We suggest that important questions for modellers to address are: (1) How does such autocorrelation of environmental quality affect simulated population trajectories? (2) How do long-lived marine animals respond to such environmental predictability?

Acknowledgements. We thank the officers and crews of the RV 'New Horizon' and David Starr Jordan for their skillful assistance. Data were collected by the authors and C. Alexander, J. Dunn, C. Elphick, R. Forster, B. Leventhal, M. Lippsmeyer, K. Molina, R. Morgan, E. Root, R. Russell, D. Sibley, K. Stowe and O. Williams. S. Gripp tacilitated access to physical data and $G$. Hemingway and $T$ Hayward provided valuable logistical assistance. We thank $D$. Schneider, $W$. Montevecchi and an anonymous revicwer for helpful comments, and E. Flint provided helpful information. This research was supported by NSF OCE 90- 19394 to J.A.M. and R.R.V.

\section{LITERATURE CITED}

Ainley DG (1976) The occurrence of seabirds in the coastal region of California. West Birds 7:33-68

Ainley DG, Sydeman WJ, Hatch SA, Wilson UW (1994) Seabird population trends along the west coast of North America: causes and extent of regional concordance. Stud Avian Biol 15:119-133

Ainley DG, Sydeman WJ, Norton J (1996) Apex predators indicate interannual negative and positive anomalies in the California Current food web. Mar Ecol Prog Ser 1.37:1-10

Br.ggs KT, Tyler WB, Lewis DB, Carlson DR (1987) Bird communities at sea off California. Stud Avian Biol 11:1-74

Carter HC, MCChesney GJ, Jaques DL, Strong CS, Parker MW, Takekawa JE, Jory DL, Whitworth DL, Point Reyes

This article was presented by D. C. Schneider (Senior Editorial Advisor), St. John's, Newfoundland, Canada
Bird Observatory and Channel Islands National Park (1992) Breeding populations of seabirds on the northern and central California coasts in 1989-1991 US Dept Interior, Minerals Mgmt Svcs, Los Angeles

Chelton DB, Bernal PA, McGowan JA (1982) Large-scale interannual physical and biological interaction in the California Current. J Mar Res 40:1095-1125

Chu EW (1984) Sooty Shearwaters off California: diet and energy gain. In: Nettleship DN, Sanger GA, Springer PF (eds) Marine birds: their feeding ecology and commercial fisheries relationships. Can Wildl Serv, Dartmouth, Nova Scotia, p 64-71

Hayward TL (1993) Prelıminary observations of the 1991-1992 El Niño in the Calitornia Current. Calif Coop Oceanic Fish Invest Rep 34:21-29

Johnson D, Shaffer T, Gould P (1991) Catch rates and estimated mortalities of marine birds in the 1989 Japanese neon squid fishery. Document U004 in Scientific review of North Pacific high seas driftnet fisheries, Sidney, BC, June $11-14,1991$. Report for presentation to the United Nations pursuant to resolutions $44 / 225$ and $45 / 197$

Manly BJF (1991) Monte Carlo methods in biology. Chapman Hall, London

Murphy RC (1936) The oceanic birds of South America. American Museum of Natural History, New York, New York

Press WH, Flannery BP, Teukolsky SA, Vettering WT (1989) Numencal recipes in PASCAL: the art of scientific computing. Cambridge University Press, Cambridge

Roemmich D (1992) Ocean warming and sea level rise along the southwest US coast. Science 257:373-375

Roemmich D, McGowan JA (1995) Climatic warming and the decline of zooplankton in the Californa Current. Science 267:1324-1326

Schneider DC, Heinemann D (1996) The status of marine bird populations from Cape Hatteras to the Gulf of Maine. In: Sherman K, Jaworski NA, Smayda T (eds) Stress, health and sustainability of manne resources: the northeast shelf ecosystem. Blackwell, London (in press)

Warham J, Wilson GJ (1982) The size of the sooty shearwater population at the Snares Islands. New Zealand Notornis 29:23-30

Wilkinson L (1988) SYSTAT the system for statistıcs. Systat, Inc, Evanston, IL.

Manuscript first received: November 4, 1994

Revised version accepted: March 27, 1996 